University of New Hampshire

University of New Hampshire Scholars' Repository

$1-1-2015$

\title{
Drought impacts on ecosystem functions of the U.S. National Forests and Grasslands: Part I evaluation of a water and carbon balance model
}

\author{
Shanlei Sun \\ Nanjing University of Information Science \& Technology \\ Ge Sun \\ United States Department of Agriculture Forest Services \\ Peter Caldwell \\ USDA-FS \\ Steve McNulty \\ United States Department of Agriculture Forest Services \\ Erika Cohen

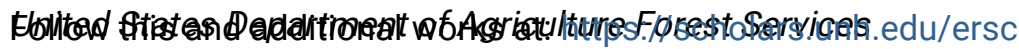 \\ Comments \\ This article was written and prepared by U.S. Government employees on official time, and is therefore in the public \\ See next page for additional authors \\ domain. This is article was published by Elsevier in Forest Ecology and Management in 2015, available online: \\ https://dx.doi.org/10.1016/j.foreco.2015.03.054
}

\section{Recommended Citation}

Sun, S., Sun, G., Caldwell, P., McNulty, S., Cohen, E., Xiao, J., Zhang, Y. (2015). Drought impacts on ecosystem functions of the U.S. National Forests and Grasslands: Part I evaluation of a water and carbon balance model. Forest Ecology and Management, 353, 260-268. https://dx.doi.org/10.1016/

j.foreco.2015.03.054

This Article is brought to you for free and open access by the Institute for the Study of Earth, Oceans, and Space (EOS) at University of New Hampshire Scholars' Repository. It has been accepted for inclusion in Earth Systems Research Center by an authorized administrator of University of New Hampshire Scholars' Repository. For more information, please contact Scholarly.Communication@unh.edu. 


\section{Authors}

Shanlei Sun, Ge Sun, Peter Caldwell, Steve McNulty, Erika Cohen, Jingfeng Xiao, and Yang Zhang 


\title{
Drought impacts on ecosystem functions of the U.S. National Forests and Grasslands: Part I evaluation of a water and carbon balance model
}

\author{
Shanlei Sun ${ }^{a}$, Ge Sun ${ }^{b}, *$, Peter Caldwell ${ }^{c}$, Steven G. McNulty ${ }^{b}$, Erika Cohen ${ }^{b}$, Jingfeng Xiao ${ }^{d}$, \\ Yang Zhang ${ }^{a}$ \\ a Department of Marine, Earth, and Atmospheric Sciences, North Carolina State University, Raleigh, NC 27606, USA \\ ${ }^{\mathrm{b}}$ Eastern Forest Environmental Threat Assessment Center, Southern Research Station, United States Department of Agriculture Forest Services, Raleigh, NC 27606, USA \\ ${ }^{c}$ Coweeta Hydrologic Laboratory, Southern Research Station, USDA-FS, Otto, NC 28763, USA \\ ${ }^{\mathrm{d}}$ Earth Systems Research Center, Institute for the Study of Earth, Oceans, and Space, University of New Hampshire, Durham, NH 03824, USA
}

\section{A R T I C L E I N F O}

\section{Article history:}

Available online 11 June 2015

\section{Keywords:}

Evapotranspiration

Gross primary productivity

National Forests and Grasslands

Water yield

Modeling

\begin{abstract}
A B S T R A C T
Understanding and quantitatively evaluating the regional impacts of climate change and variability (e.g. droughts) on forest ecosystem functions (i.e., water yield, evapotranspiration, and productivity) and services (e.g., fresh water supply and carbon sequestration) is of great importance for developing climate change adaptation strategies for National Forests and Grasslands (NFs) in the United States. However, few reliable continental-scale modeling tools are available to account for both water and carbon dynamics. The objective of this study was to test a monthly water and carbon balance model, the Water Supply Stress Index (WaSSI) model, for potential application in addressing the influences of drought on NFs ecosystem services across the conterminous United States (CONUS). The performance of the WaSSI model was comprehensively assessed with measured streamflow (Q) at 72 U.S. Geological Survey (USGS) gauging stations, and satellite-based estimates of watershed evapotranspiration (ET) and gross primary productivity (GPP) for 170 National Forest and Grassland (NFs). Across the 72 USGS watersheds, the WaSSI model generally captured the spatial variability of multi-year mean annual and monthly $Q$ and annual ET as evaluated by Correlation Coefficient $(R=0.71-1.0)$, Nash-Sutcliffe Efficiency (NS $=0.31-1.00$ ), and normalized Root Mean Squared Error (0.06-0.48). The modeled ET and GPP by WaSSI agreed well with the remote sensing-based estimates for multi-year annual and monthly means for all the NFs. However, there were systemic discrepancies in GPP between our simulations and the satellite-based estimates on a yearly and monthly scale, suggesting uncertainties in GPP estimates in all methods (i.e., remote sensing and modeling). Overall, our assessments suggested that the WaSSI model had the capability to reconstruct the long-term forest watershed water and carbon balances at a broad scale. This model evaluation study provides a foundation for model applications in understanding the impacts of climate change and variability (e.g., droughts) on NFs ecosystem service functions.
\end{abstract}

Published by Elsevier B.V.

\section{Introduction}

Forest water yield $(Q)$, evapotranspiration (ET), gross primary productivity (GPP), and net primary productivity (NPP) are the critical ecosystem functions (Xiao et al., 2008, 2010; Jung et al., 2010; Sun et al., 2011a, 2011b) that sustain many ecosystem services, such as stable and high quality water supply, carbon sequestration, climate regulation, and biodiversity conservation. For example,

* Corresponding author at: Eastern Forest Environmental Threat Assessment Center, Southern Research Station, USDA Forest Service, 920 Main Campus Dr., Venture II, Suite 300, Raleigh, NC 27606, USA. Tel.: +1 9195159498; fax: +1 9192735154.

E-mail address: gesun@fs.fed.us (G. Sun). over half of U.S. fresh water supply originates from forests and grasslands (Brown et al., 2008; Sun et al., 2015a, 2015b). It is estimated that forests and grasslands offset $10-40 \%$ of annual carbon emissions from burning fossil fuels each year of the U.S. (Ryan et al., 2010; McKinley et al., 2011; Xiao et al., 2011). However, with a changing climate, the tightly coupled water and carbon cycles are changing from the leaf to global scales (IPCC, 2014). Consequently, there are concerns about the diminishing potential for forest ecosystem services under a changing environment (Zhao and Running, 2010).

To meet the American publics' demand for stable and abundant water, timber supply, recreation, and other ecosystem goods and services, the U.S. National Forest and Grassland System (NF) was 
established over a century ago. Now the NF lands cover about $781,000 \mathrm{~km}^{2}$ (193 million acres) or about $8.8 \%$ of the total land area of the U.S. The top priority of the USDA-Forest Service is to sustain ecosystem health, diversity, and productivity to meet the needs of present and future generations. However, ongoing climate variability and change and related environmental impacts have exerted serious threats to NFs stability and thus their ability to deliver ecosystem services (NCA, 2014). A comprehensive quantitative assessment of global change impacts, particularly for climate extremes (e.g., droughts), on the ecosystem services of NFs is urgently needed for land managers and policy makers to develop sound mitigation and adaptation strategies (Vose et al., 2012; NCA, 2014).

Over the last decade, numerous tools have been developed to quantify regional carbon fluxes and stocks including machine-learning techniques (Xiao et al., 2008, 2010, 2011; Jung et al., 2009; Zhang et al., 2011), remote sensing-based diagnostic models (Mu et al., 2007), process-based ecosystem models (Xiao et al., 2009; Tian et al., 2010), atmospheric inverse modeling (Deng et al., 2007) and inventory methods (Pacala et al., 2001). These approaches are typically not designed to simulate water and carbon fluxes using watersheds as the smallest modeling unit. In addition, the short temporal span of remote sensing data of land cover and biophysical parameters needed for model application (e.g. 10 years) will limit our ability to explore historical drought impacts on water and carbon cycles. Considering the limitations of these methods, Sun et al. (2011b) developed a water-centric monthly scale model (WaSSI) that operates at 2103 Watershed Boundary Database (WBD) 8-digit Hydrologic Unit Code (HUC) watersheds across the conterminous U.S. (CONUS). Algorithms were derived on the basis of empirical water and carbon flux measurements from the FLUXNET network. The WaSSI model has been used to quantitatively assess the combined or separate effects of climate change, land cover change, and population dynamics on past and future water supply stress and ecosystem productivity over the CONUS, and can be easily implemented because few input climatic variables are needed and no model calibration is necessary. The model has been applied in Mexico, China and some African countries (Sun et al., 2008, 2011b; Lockaby et al., 2011; Caldwell et al., 2012; Averyt et al., 2013; Tavernia et al., 2013; Liu et al., 2013; Marion et al., 2014; McNulty et al., 2015).

Recently, the WaSSI model was upgraded to a higher spatial resolution of 12-digit HUC (88,000 watersheds) compared to the previous 8-digit HUC (2103 watersheds) across the CONUS. The overall goal of this study was to validate the improved version of the WaSSI, and to then use the model to examine impacts of long-term climate variability on $Q$ ET and GPP, under droughts in selected NFs. The specific objectives of the study were: (1) to evaluate model performance by comparing WaSSI estimates to the measured $Q$ at 72 U.S. Geological Survey (USGS) gauges within the 170 NFs (1990-2009); (2) to evaluate model performance by comparing simulated ET (2000-2012) and GPP (2001-2012) against satellite-based estimates for $170 \mathrm{NFs}$; and (3) to reconstruct a long-term $Q$ ET and GPP time-series (1960-2012) of the $170 \mathrm{NFs}$ over the CONUS.

This paper reports multi-year comprehensive model validation results. Model application to study the drought impacts on NFs is found in a follow-up paper in this issue (Sun et al., 2015b).

\section{Methods}

\subsection{Study area}

The research area for this modeling study was the NFs over the CONUS, mainly including 150 National Forest and 20 National Grasslands. The NFs (see Supplementary materials s1) cover about approximately $781,000 \mathrm{~km}^{2}$ (193 million acres), or $9 \%$ of the CONUS land area. More than $70 \% \mathrm{NFs}$ are located in the Northwest and the Southwest regions (Fig. 1a). Climate, topography, and vegetation cover vary dramatically among these 170 NFs. For example, mean annual precipitation varies from $300 \mathrm{~mm} \mathrm{yr}^{-1}$ at the Crooked River National Grassland (the Oregon State) to $3000 \mathrm{~mm} \mathrm{yr}^{-1}$ at the Olympic National Forest in the state of Washington (Fig. 1b). Eighty-five (50\%) of the NFs had a multi-year mean annual precipitation below $1000 \mathrm{~mm} \mathrm{yr}^{-1}$ and a multi-year mean temperature lower than $10^{\circ} \mathrm{C}$. Forty-six (27\%) of the NFs had mean annual precipitation and temperature ranging from 1000 to $2000 \mathrm{~mm} \mathrm{yr}^{-1}$ and from 10 to $20^{\circ} \mathrm{C}$, respectively. Grasslands were found in the West and Southwest region with mean precipitation below $600 \mathrm{~mm} \mathrm{yr}^{-1}$.

\subsection{The WaSSI model}

The WaSSI model was originally designed and applied to the southeastern U.S. at the USGS 8-digit HUC watershed scale to model water supply and demand on an annual time-step (Sun et al., 2008) and later it was improved to simulate both water and carbon balances at a monthly scale for the CONUS (Sun et al., 2011b; Caldwell et al., 2012). An internet version of model and user guide is available (http://www.forestthreats.org/research/tools/WaSSI). The WaSSI model has been updated to operate at a monthly, 12-digit HUC scale. WaSSI is an integrated, process-based model that describes key ecohydrological processes at a broad scale (Sun et al.,
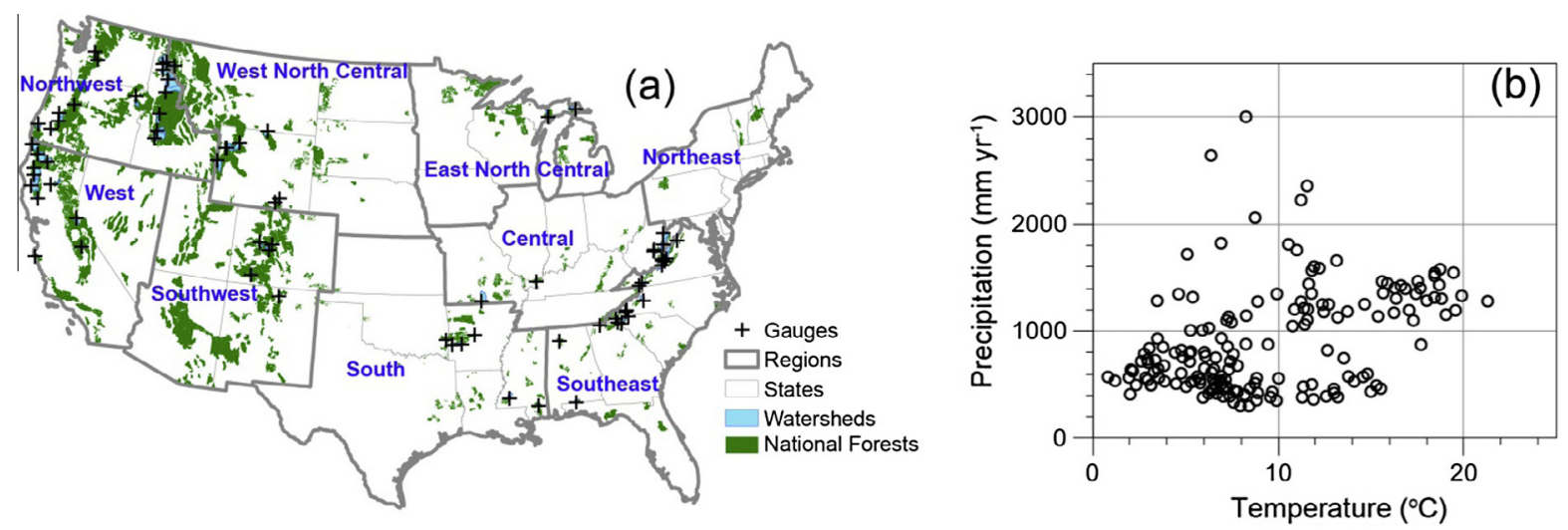

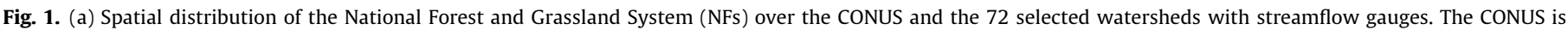

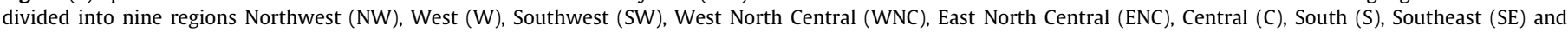
Northeast (NE). (b) Climate (multi-year mean annual precipitation and temperature) space of the NFs showing a large climatic gradient. 
2011a; Caldwell et al., 2012; Sun et al., 2015a, 2015b). It can predict water and carbon balances, such as ET, soil water storage, $Q$, GPP and NEE for each of eight land cover types within a given watershed, and then aggregates these fluxes to the whole basin using area-weighted averaging. Three sub-models are integrated within the WaSSI model framework. The water balance sub-model computes ecosystem water use (i.e., ET), and $Q$ generated from each watershed. Herein, $Q$ is the amount of water yield 'produced' in each watershed assuming that the water balances within each watershed are in isolation without any flow contribution from upstream watersheds. The carbon balance sub-model simulates monthly carbon gains (GPP) and losses (i.e., ecosystem respiration) in each watershed as functions of ET and GPP, respectively (Sun et al., 2011b). The water supply and demand sub-model routes and accumulates $Q$ through the river network according to topological relationships between adjacent watersheds, subtracts consumptive water use by humans from river flows, and compares water supply to water demand to compute the water supply stress index. In this study, we focused on the model performance in predicting $Q$ ET and GPP, thus only detailed information about the sub-models of water and carbon balances is described below. For a complete description of the WaSSI model, the readers can refer to the WaSSI User's Guide (http://www.forestthreats.org/ research/tools/WaSSI/WaSSIUserGuide_english_v1.1.pdf).

\subsubsection{Water balance sub-model}

The WaSSI model operates at a watershed scale assuming uniform climate across the watershed but with mixed land covers. The model first partitions monthly precipitation into rainfall and snowfall by watershed. A conceptual snow model (McCabe and Wolock, 1999; McCabe and Markstrom, 2007) is employed for partitioning monthly precipitation based on the mean watershed elevation and the monthly air temperature, estimating snow melt rates, and calculating mean monthly snow water equivalent (SWE). Snow accumulation is simulated and reported as one key output variable. Critical parameters for the snow partitioning and melting models are derived by model calibration for each USGS Water Resource Region (WRR) by comparing predicted regional monthly mean SWE to remotely sensed SWE from the Snow Data Assimilation System (National Operational Hydrologic Remote Sensing Center, 2004). Infiltration, surface runoff, soil moisture, and baseflow processes for each land cover type are simulated by the Sacramento Soil Moisture Accounting Model (SAC-SMA; Burnash, 1995). The SAC-SMA model has been used successfully by the National Oceanic and Atmospheric Administration (NOAA) National Weather Service (NWS) for river flood forecasting for decades; and State Soil Geographic Data Base (STATSGO; Natural Resources Conservation Service, 2012) derived SAC-SMA soil input parameters to drive the model has been developed, tested, and made available for the CONUS (Koren et al., 2003, 2005; Anderson et al., 2006).

Monthly water loss as ET for each land cover type in each watershed was first approximated as function of potential ET, leaf area index (LAI), and precipitation (Sun et al., 2011a, 2011b). The empirical regression model is the core of the water balance sub-model and was derived from ecosystem-level ET measurements by eddy covariance or sapflow techniques across more than 240 research sites spanning a large climatic gradient (Sun et al., 2011a, 2011b). In addition to land cover diversity, management practices also vary widely across these sites. Since ET may be overestimated under extreme water-limited conditions, ET calculated by the regression model is further constrained. Within the WaSSI model, the two-soil-layer SAC-SMA algorithm is used to compare ET demand to soil water storage, and then limit ET if soil water is not sufficient to meet the demand. Soil moisture for ET is withdrawn sequentially from the upper soil layer tension water storage (i.e., soil water tension between field capacity and the wilting point), upper layer free water storage (i.e., soil water tension between saturation and field capacity), and from the lower layer tension water storage until the demand is met or until available soil water has been depleted.

\subsubsection{Carbon balance sub-model}

Previous studies have suggested that ecosystem ET and GPP are closely coupled at a monthly scale, and this simple linear relationship has been found in a number of forest ecosystems (Law et al., 2002; Xie et al., 2013). Sun et al. (2011b) developed a set of relationships between ET and GPP for 11 ecosystem types by synthesizing global eddy flux data (e.g., FLUXNET LaThuie dataset; http://www.fluxdata.org). These relationships allow for dynamic modeling of ET and GPP, and linking climate, water, and carbon balances at a broad scale. Although the model does not simulate the detailed processes of carbon cycling, it does account for the major control of carbon balances (i.e., soil moisture availability and energy availability).

\subsubsection{Model parameterization}

To run the WaSSI model, the necessary inputs include monthly precipitation, monthly mean air temperature, monthly LAI by land cover, land cover composition within each watershed, and 11 SAC-SMA soil parameters. All the input data were re-scaled to the 12-digit HUC watershed scale from gridded data with different spatial resolutions. The historical climate dataset $(4 \times 4 \mathrm{~km}$ resolution) during 1961-2012 was derived from the Precipitation Elevation Regression on Independent Slopes Model (Daly et al., 1994; PRISM Climate Group, 2013). The land cover distribution was based on the 2006 National Land Cover Dataset $(30 \times 30 \mathrm{~m}$ resolution; http://www.mrlc.gov/nlcd06_data.php) with 17 land cover classes (Fry et al., 2011) aggregated into ten classes: crop, deciduous forest, evergreen forest, mixed forest, grassland, shrubland, wetland, water, urban and barren. Monthly LAI data were derived from the MODIS-MOD15A2 FPAR/LAI 8-day product (Myneni et al., 2002). Within each watershed, the multi-year mean monthly LAI database for each land cover type was individually constructed. The State Soil Geographic Data Base (STATSGO)-based SAC-SMA soil parameter dataset $(1 \times 1 \mathrm{~km}$ resolution) was provided by the National Oceanic and Atmospheric Administration-National Weather Service (NOAA-NWS) Hydrology Laboratory, Office of Hydrologic Development.

\subsection{Model evaluation}

To evaluate the WaSSI model performance in simulating the water balance and carbon cycles in NFs, the simulated $Q$ ET and GPP were compared against the streamflow measured at 72 USGS gauges and MODIS remote sensing products for ET (20002012) and GPP (2001-2012), respectively. The annual watershed-scale ET (1961-2009) estimated by the watershed balances, $P$ minus $Q$ for 72 gaged watersheds was also used to evaluate WaSSI performance in simulating long-term ET, a major control on $Q$. The watershed water balance method assumed that the change in soil water storage was negligible over a long term (Brown et al., 2008; Sun et al., 2011b).

The observed monthly streamflow data between 1990 and 2009 were acquired from the USGS reference stations that have not been subject to human disturbances (http://waterdata.usgs.gov/nwis/ $\mathrm{rt}$ ). For model validation purposes, we used the following three criteria to identify the USGS gauged watersheds that are most comparable to the 12-digit HUC watersheds within the NFs. First, several 12-digit HUC watersheds could be integrated to match the corresponding USGS gauged watersheds to reduce the watershed boundary mismatch errors. Second, the selected gauged watersheds must overlap more than $50 \%$ with the NFs. Third, the 
selected gauged watersheds should not receive flow from any upstream watersheds. The resulting USGS streamflow data were then directly comparable to the predicted $Q$ by WaSSI. All 72 USGS gauged watersheds met these three criteria and were selected for model validation.

Satellite-derived ET and carbon flux (e.g., GPP) products were available for regional model validation purposes (Cleugh et al., 2007; Mu et al., 2007; Fisher et al., 2008; Zhang et al., 2014). This is one type of the widely used ET datasets developed by $\mathrm{Mu}$ et al. (2007) based on reanalysis of surface meteorological data from NASA's Global Modeling and Assimilation Office with MODIS land cover, albedo, LAI and the Fraction of Absorbed Photosynthetically Active Radiation (FPAR) inputs. The MODIS ET algorithms for regional and global ET mapping and monitoring have been evaluated with AmeriFlux flux datasets. The new MODIS ET product (2000-2012) ( $1 \times 1 \mathrm{~km}$ grid resolution) (Mu et al., 2011) was used in the present study. We also used gridded GPP data from the EC-MOD products (Xiao et al., 2008, 2010, 2011,2014 ) that were derived from eddy covariance flux observations and MODIS data streams for the period 2001-2012. A data-driven approach (Xiao et al., 2014) was used to upscale carbon fluxes from eddy covariance flux sites to the continental-scale and to produce the EC-MOD flux estimates with $1 \times 1 \mathrm{~km}$ spatial resolution and 8-day time step for the period 2001-2012 (Xiao et al., 2010, 2011, 2014). The MODIS ET and EC-MOD GPP datasets provided the independent estimates of ET and ecosystem productivity for evaluating the WaSSI model predictions. For comparison purposes, these gridded satellite-derived datasets were aggregated from 8-day to monthly sums, and then were rescaled to the NFs scale by spatial weighted averaging. Similarly, the simulated monthly datasets for each NFs was developed by weighing the area fractions of the 12-digit HUC within each NFs.

The model performance in simulating $Q$, ET and GPP was evaluated using scatterplots and difference maps (observed minus predicted), root-mean-square-error (RMSE), mean relative error $(M R E)$, correlation coefficient $(R)$, and slopes of the linear regression models. We validated the model against various reference products of multi-year mean $Q$, ET and GPP, and annual $Q$. As an additional criterion for $Q$ evaluation, the Nash-Sutcliffe Efficiency statistic ( $E_{\mathrm{NS}}$; Nash and Sutcliffe, 1970) was also selected, and this statistic is expressed as:

$E_{\mathrm{NS}}=1-\frac{\sum_{i=1}^{n}\left(V_{o, i}-V_{s, i}\right)^{2}}{\sum_{i=1}^{n}\left(V_{o, i}-V_{o}\right)^{2}}$

where $n$ is the number of observations during the evaluation period; $V_{O, i}$ and $V_{S, i}$ are the observed and simulated values at each point $i$, respectively; and $V_{O}$ is the arithmetic mean of observations. An $E_{\mathrm{NS}}$ value of 1.0 represents a perfect model fit.

\section{Results}

\subsection{Model evaluation of water yield (Q) and ET as estimated by $P$ minus Q for 72 USGS gauged watersheds}

The comparisons between model simulated and observed mean annual $Q$ for the 72 watersheds during 1990-2009 (Fig. 2a and Table 1 ) indicated that the WaSSI model performed well over the long term as judged by model statistics $(R=0.97$; mean slope $=0.86 ; R M S E=12 \mathrm{~mm} \mathrm{yr}^{-1} ;$ MRE $=4 \%$ ). Overall, the model could match annual $Q$ well for most of the watersheds, but underestimated flow for a few watersheds with high flow rates. The multi-year mean annual modeled $Q$ values were significantly correlated to measured $Q$, and all data samples were clustered around the $1: 1$ line, suggesting that this model could capture the spatial variability as well. Except for the peaks in May and June, simulated intra-annual fluctuations of $Q$ matched the measured $Q$ reasonably well when all data for the selected 72 USGS watersheds were pooled together (Fig. 3a). Monthly $Q$ generally increased from January to May with a peak of $102 \mathrm{~mm} \mathrm{yr}^{-1}$ and $86 \mathrm{~mm} \mathrm{yr}^{-1}$ in May for the observed and simulated values, respectively. Monthly flows drastically decreased during the summer growing season and reached the lowest values in August $\left(21 \mathrm{~mm} \mathrm{yr}^{-1}\right)$ for the observed, and September $\left(26 \mathrm{~mm} \mathrm{yr}^{-1}\right)$ for the simulated. The fall season is the groundwater recharge period and streamflow increased as a result of decreased ET (Fig. 3b).

The simulated and the observed multi-year mean annual $Q$ exhibited a similar spatial pattern across the selected 72 USGS watersheds (Fig. 4a). $Q$ was the highest ( $>900 \mathrm{~mm} \mathrm{yr}^{-1}$ ) in watersheds of the west coastal region and the southern Appalachian Mountains, mainly due to both moderate ET rates and high precipitation. Most watersheds of the WNC, SW and ENC regions generated very little $Q\left(<500 \mathrm{~mm} \mathrm{yr}^{-1}\right)$ because of low precipitation and high evaporative demand. Multi-year mean differences in annual $Q$ between the USGS observations and the WaSSI simulations showed a complex pattern (Fig. 4c). In the NW and NWC regions, and the Appalachian Mountains, the model overestimated $Q$ for most watersheds, especially for the NW coast (discrepancy $Q>120 \mathrm{~mm} \mathrm{yr}^{-1}$ ). However, for most of the 72 watersheds, the WaSSI model underestimated $Q$ to different degrees (Fig. 4c).

The spatial distributions of the slopes of the linear regression models, the normalized RMSE, $R$ and $E_{\mathrm{NS}}$ provided a complete picture of model performance in modeling $Q$ (Fig. 5). Among the 72 watersheds, 44 and 66 watersheds had regression slopes higher than 0.80 and normalized RMSE values lower than 0.30 , respectively, indicating that the WaSSI model simulated the magnitudes of annual $Q$ well for most watersheds (Fig. 5a and b). Similarly, 55 watersheds had $R$ values higher than 0.90 , suggesting that WaSSI captured the inter-annual fluctuations of $Q$ (Fig. 5c). Except for few watersheds on the west coast and the Great Plains, 50 watersheds had $E_{\mathrm{NS}}$ values ranging from 0.60 to 1 (Fig. $5 \mathrm{~d}$ ), implying that the model accurately predicted annual $Q$, especially for the humid SE region.

A comparison between simulated ET by WaSSI and estimated ET as the differences between precipitation and measured USGS streamflow provided more confidence in model annual streamflow (Fig. 2b). The simulated annual ET and estimated ET as $P-Q$ were highly correlated $(R=0.86)$ with a moderate $R M S E$ of $106 \mathrm{~mm} \mathrm{yr}^{-1}$ and MRE of $16 \%$. Although the modeled ET values matched well with estimated in the low ET range ( $\left.<450 \mathrm{~mm} \mathrm{yr}^{-1}\right)$, over estimations were obvious for seven watersheds (Fig. 2b).

\subsection{Model evaluation by ET for 170 NFs}

The scatterplot of the measured $(P-Q)$ vs. the predicted multi-year mean annual ET (2000-2012) provided evidence for the model's capability to simulate ET (Fig. 2b). The predicted ET across the $170 \mathrm{NFs}$ was significantly correlated to the satellite-based estimates with $R$ of 0.92 . Moreover, the observed and the simulated multi-year mean ET in most of the NFs were distributed around the 1:1 line with RMSE of $104 \mathrm{~mm} \mathrm{yr}^{-1}$ and MRE of $16 \%$ (Table 1). However, WaSSI both over- and under- predicted ET compared to satellite-based ET estimates (Fig. 2b). At the monthly scale, the WaSSI model matched the mean variations of monthly ET derived from satellite-based MODIS data. Generally, monthly ET peaked in July, and after that ET began to decline. During April-June and September, the WaSSI model slightly underestimated monthly ET, and overestimated ET in the winter months ( $>7 \mathrm{~mm} \mathrm{month}^{-1}$ ).

The WaSSI model captured the spatial patterns of NFs ET generally well when compared to the satellite-based data (Fig. 4d and e). 

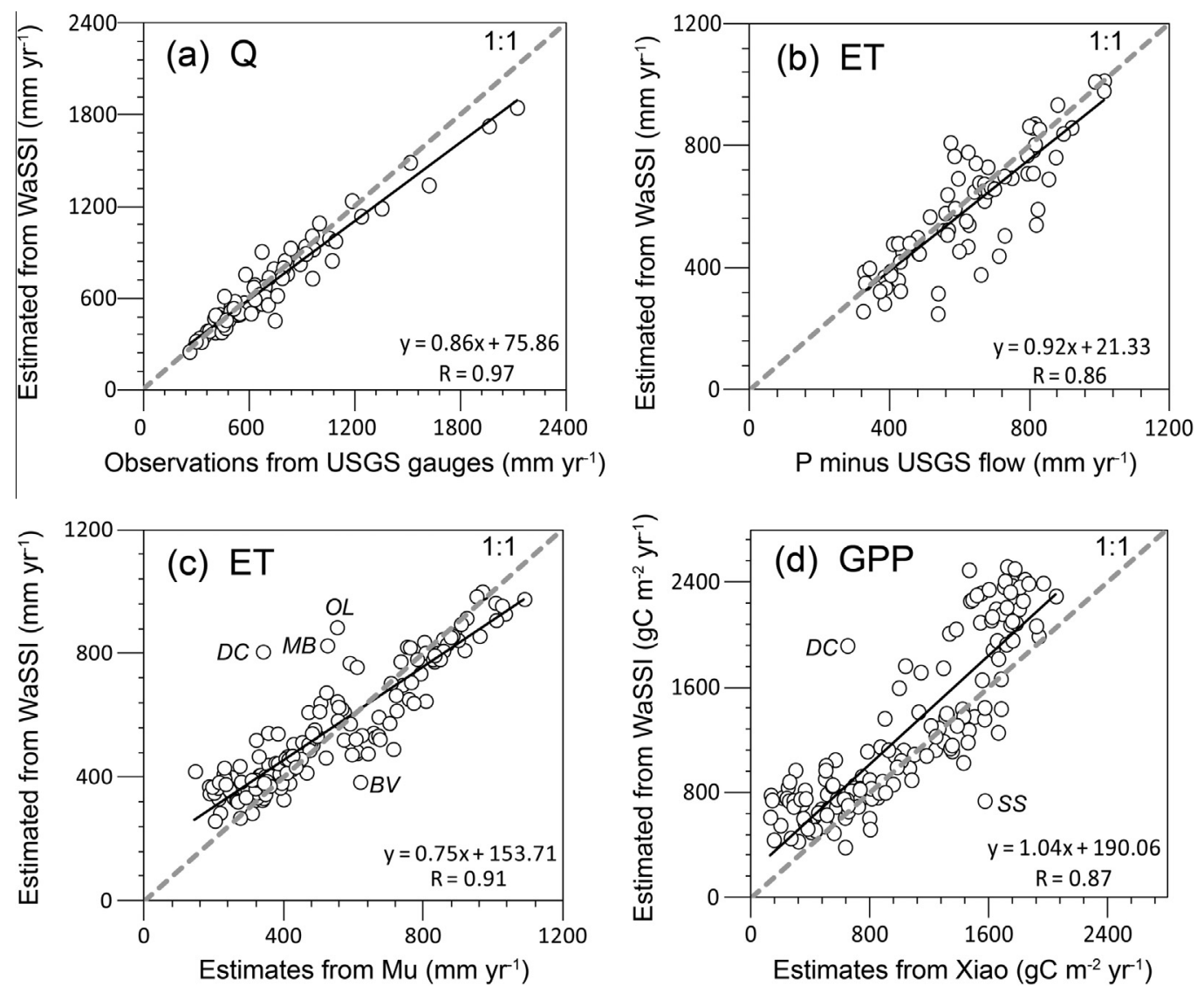

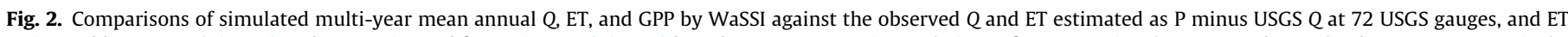

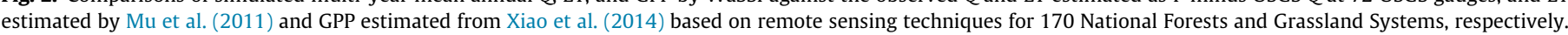

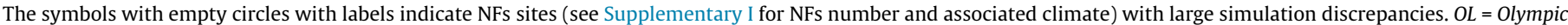

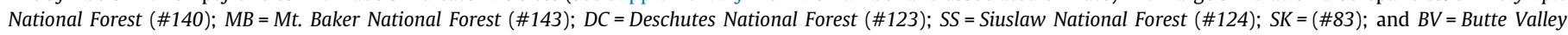
National Grassland (\#82).

Table 1

A summary of WaSSI model performance in simulating $Q$. ET across the 72 watersheds (1990-2009), and ET and GPP across the 170 NFs (2000-2012).

\begin{tabular}{|c|c|c|c|c|}
\hline \multirow[t]{2}{*}{ Variables compared } & \multicolumn{2}{|c|}{ Multi-year mean \pm SD } & \multirow{2}{*}{$\begin{array}{l}\text { Root mean } \\
\text { square } \\
\text { error }\end{array}$} & \multirow{2}{*}{$\begin{array}{l}\text { Mean } \\
\text { relative } \\
\text { error (\%) }\end{array}$} \\
\hline & $\begin{array}{l}\text { Observed/ } \\
\text { Estimated }\end{array}$ & $\begin{array}{l}\text { WaSSI } \\
\text { Simulated }\end{array}$ & & \\
\hline USGS $Q\left(\mathrm{~mm} \mathrm{yr}^{-1}\right)$ & $716 \pm 397$ & $688 \pm 342$ & 12 & 4 \\
\hline $\begin{array}{l}\text { ET estimated as } P \\
\text { minus USGS } Q \\
\left(\mathrm{~mm} \mathrm{yr}^{-1}\right)\end{array}$ & $595 \pm 195$ & $625 \pm 181$ & 106 & 13 \\
\hline MODIS ET(mm yr $\left.{ }^{-1}\right)$ & $516 \pm 232$ & $534 \pm 196$ & 104 & 16 \\
\hline $\begin{array}{l}\text { EC-MOD GPP } \\
\qquad\left(\mathrm{gC} \mathrm{m}^{-2} \mathrm{yr}^{-1}\right)\end{array}$ & $1012 \pm 528$ & $1254 \pm 642$ & 380 & 28 \\
\hline
\end{tabular}

The SE region had the highest ET ( $\left.>700 \mathrm{~mm} \mathrm{yr}^{-1}\right)$, particularly for those near the coast $\left(>900 \mathrm{~mm} \mathrm{yr}^{-1}\right)$. For the west coast and the ENC and NE regions, most NFs had the moderate ET ranging from $500 \mathrm{~mm} \mathrm{yr}^{-1}$ to $700 \mathrm{~mm} \mathrm{yr}^{-1}$. The NFs in the SW, WNC regions and the east NW and $\mathrm{W}$ exhibited the lower ET $\left(<500 \mathrm{~mm} \mathrm{yr}^{-1}\right)$. Overall, the WaSSI model tended to underestimate ET in the eastern U.S. and overestimated ET in the western U.S., especially for some NFs of the northwestern and southwestern U.S. with modeling errors greater than $100 \mathrm{~mm} \mathrm{yr}^{-1}$.

\subsection{Model evaluation by GPP for $170 \mathrm{NFS}$}

The scatterplot of measured vs. predicted multi-year mean annual GPP indicated good model performance overall $(R=0.87$ and a slope near to 1.0). The RMSE (380 $\mathrm{gC} \mathrm{m}^{-2} \mathrm{yr}^{-1}$ ) and MRE (28\%) values were moderate (Table 1 ). However, the simulated multi-year means for most NFs were above the 1:1 line, suggesting that there might be systemic discrepancies between the WaSSI modeled and the satellite-based GPP. The WaSSI modeled GPP had similar seasonal patterns as the satellite-based estimates. Both WaSSI-modeled and remote sensing-based estimates of monthly GPP peaked in July, $183 \mathrm{gC} \mathrm{m}^{-2} \mathrm{yr}^{-1}$ and $167 \mathrm{gC} \mathrm{m}^{-2} \mathrm{yr}^{-1}$, respectively. It suggests that systemic discrepancies existed in the multi-year mean monthly GPP (Fig. 3c). WaSSI overestimated monthly GPP for the whole of 170 NFs, especially for winter and spring months $\left(>18 \mathrm{gC} \mathrm{m}^{-2} \mathrm{month}^{-1}\right)$ compared to the satellite-based estimates.

For spatial patterns of multi-year mean annual GPP, the WaSSI simulations were similar to the satellite-based estimates (Fig. 4g and 4h). The highest GPP (>1600 $\left.\mathrm{gC} \mathrm{m}^{-2} \mathrm{yr}^{-1}\right)$ was found in the SE region while the moderate GPP values (1000$1600 \mathrm{gC} \mathrm{m}^{-2} \mathrm{yr}^{-1}$ ) were mainly located in the west coast and the ENC and NE regions. However, the western part of the CONUS, excluding the west coast, had relatively low GPP $\left(<800 \mathrm{gC} \mathrm{m}^{-2} \mathrm{yr}^{-1}\right)$. Despite the similar spatial patterns for GPP estimates by the two methods, some spatial differences were noted (Fig. 4i). The WaSSI model overestimated GPP in the S and SE regions and the east part of WNC $\left(>300 \mathrm{gC} \mathrm{m}^{-2} \mathrm{yr}^{-1}\right)$ compared to MODIS-based GPP data. Nevertheless, the NFs in the California and the NE region with the negative GPP differences suggested that GPP was underestimated by the WaSSI model. 

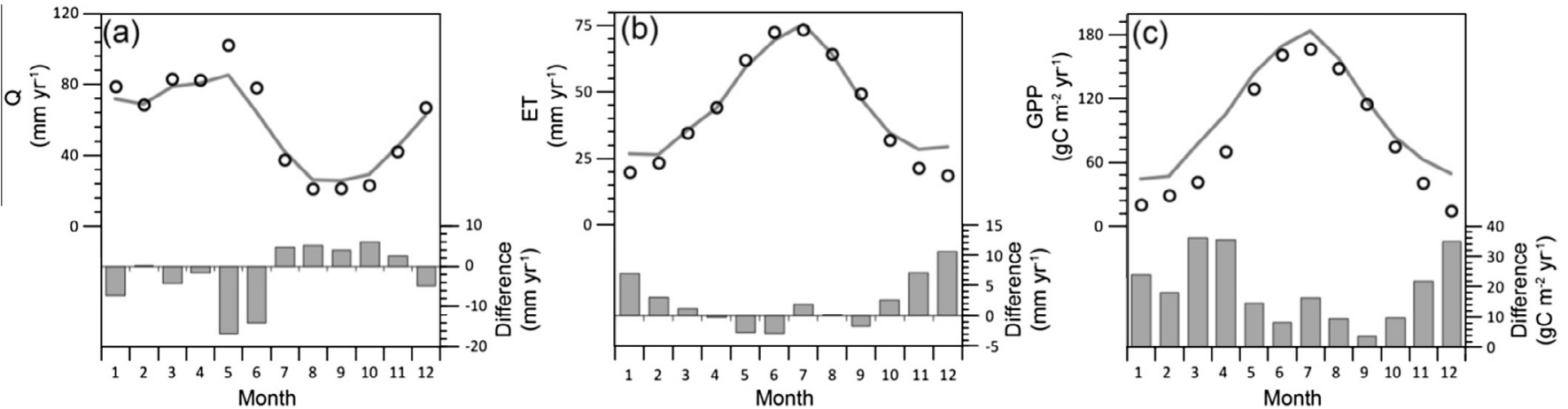

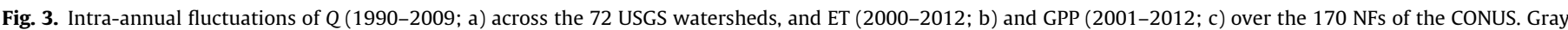

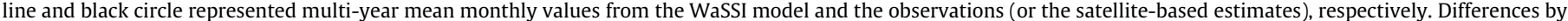
the simulated minus the measured (or the satellite-based estimates) were shown with the gray bars.

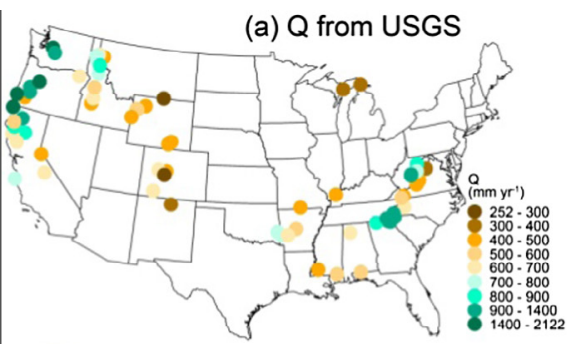

(d) ET from $\mathrm{Mu}$

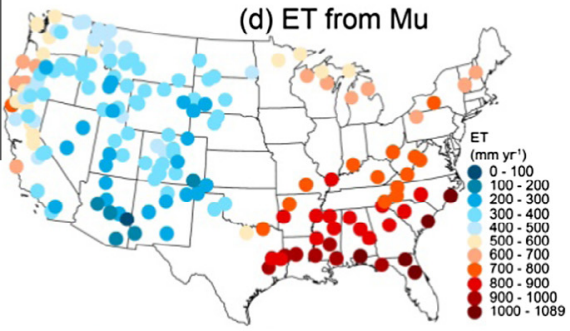

(g) GPP from Xiao

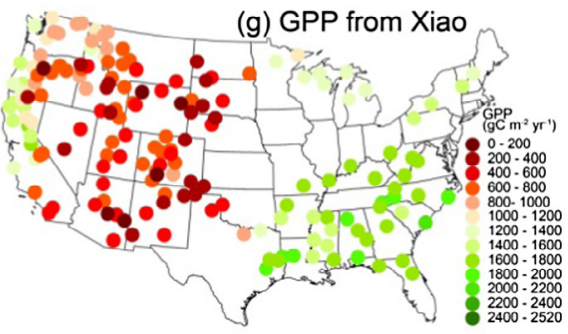

(b) $Q$ from WassI

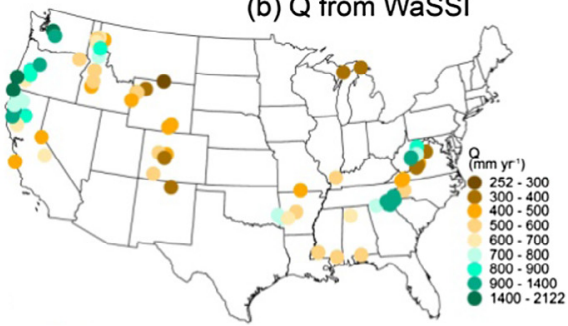

(e) ET from WaSSI

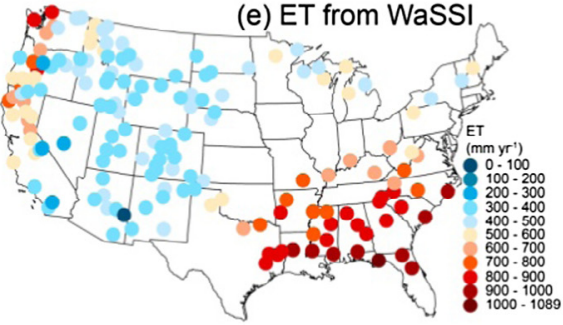

(h) GPP from WaSSI

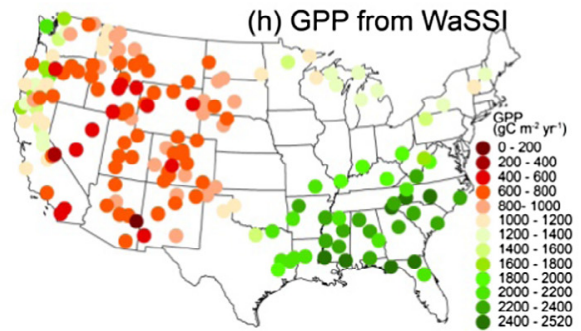

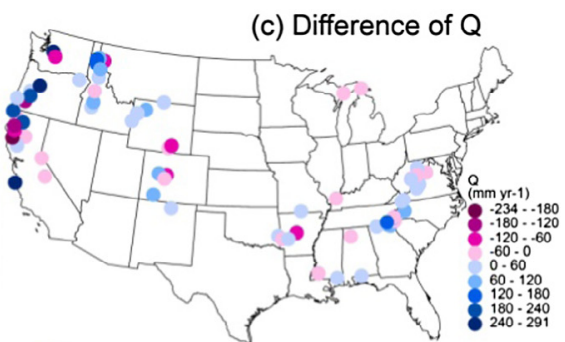

(f) Difference of ET

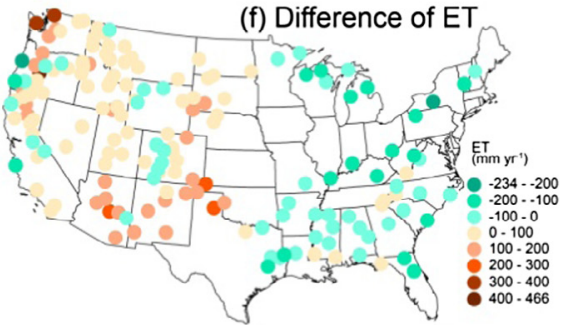

(i) Difference of GPP

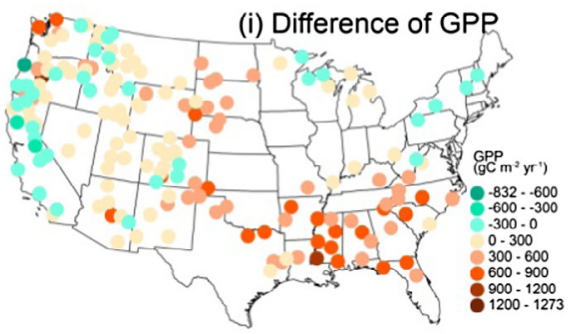

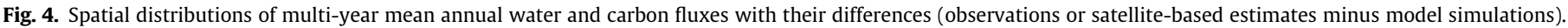

\section{Discussion}

\subsection{Outliers of ET and GPP predicted by WaSSI}

Our multi-watershed and NFs-wide model evaluation suggested that the WaSSI model was effective for estimating annual watershed water and carbon balances. Our simulations generally agreed well with watershed observations and gridded MODIS ET (Mu et al., 2011) and EC-MOD GPP (Xiao et al., 2010, 2014) products. The large discrepancies between WaSSI simulations and the gridded ET and GPP products for a few NFs (with the italic characters in Fig. 2b and c) could be attributed to the fragmentation of NFs and the mis-match of watershed boundaries. These NFs had irregular boundaries and land cover compositions. The WaSSI model operated at the 12-digit HUC watershed level, but the presentation of simulated results for each NFs was computed through weighted averages using the area fraction of the 12-digit HUC watershed that fell within each NFs. Therefore, ET and GPP estimates for each NFs were influenced by the dominant land cover within each watershed, and therefore bias could occur, particularly for the smaller and more fragmented NFs. Mis-classification of land cover types was also possible by MODIS products, resulting in erroneous estimates of ET and GPP by either WaSSI or the remote sensing-based methods. 

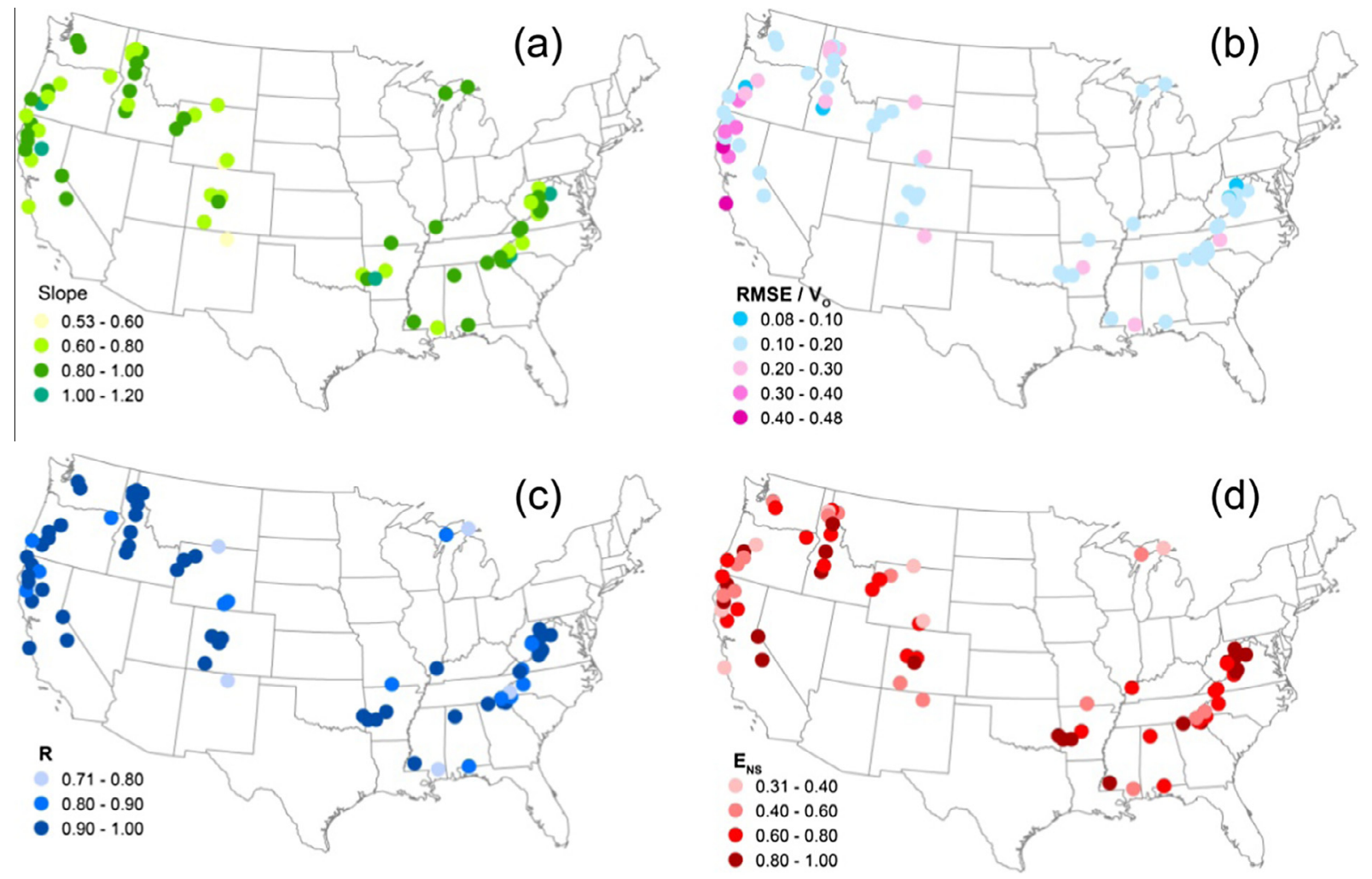

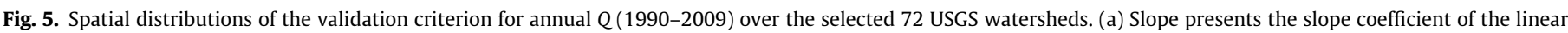

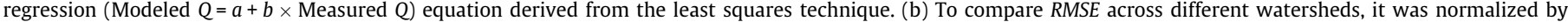

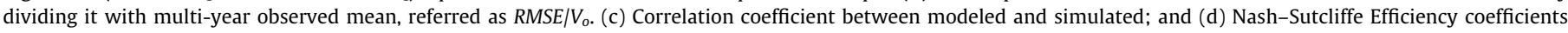
$\left(E_{\mathrm{NS}}\right)$.

\subsection{Uncertainties of modeled water balance}

Similar to other hydrologic models, simulated $Q$ and ET by the WaSSI model were subject to uncertainties due to the following factors: input data issues including potential errors in climate data, land cover, soil and LAI estimates from remote sensing as well as from the incomplete representation of the hydrological processes. A recent study suggests the PRISM data might have overestimated the magnitude of climatic warming in high elevation mountainous regions in western U.S. with complex terrains (Oyler et al., 2015). An over estimating air temperature rise by the PRISM then may result in over estimating PET, ET, and underestimating $Q$. The present study assumed that the monthly LAI values in the historic period prior to 2000 were the same as the $2000-2012$ period because MODIS LAI data only became available in 2000. This assumption might result in LAI errors for some NFs watersheds given that both climate and atmospheric $\mathrm{CO}_{2}$ concentrations have changed substantially during the past 50 years, altering forest ecosystem structure (LAI), tree species compositions, and ecosystem processes (i.e., ET processes) (Piao and Fang, 2003; Gedney et al., 2006). In addition, this study did not consider management activities such as logging, forest thinning, prescribed burning, and other natural disturbances (i.e., wildfire, insect and disease out breaks, hurricanes) in NFs. These disturbances have likely affected forest dynamics and ecosystem processes in some NFs over this time period (Vose et al., 2012; Masek et al., 2013).

\subsection{Uncertainties of modeled ecosystem productivity}

Despite the general agreement that North American ecosystems have a large capability for carbon sequestration, uncertainties exist in the size and distribution of ecosystem productivity by existing estimates by different methods (Goodale et al., 2002; Gurney et al., 2002; Deng et al., 2007; Xiao et al., 2011, 2014). Similarly, there were discrepancies between GPP estimated by the WaSSI model in this study and the estimates based on satellite data (Xiao et al., 2014). As shown in Fig. 2c, the simulated multi-year mean GPP by WaSSI were generally higher when compared against the satellite-based data, indicating that there were large uncertainties in estimating GPP by the two methods. Xiao et al. (2008, 2011, 2014) examine the effects of disturbance (e.g., hurricane, fire, pest and pathogen), stand age and nitrogen availability on ecosystem carbon dynamics and conclude that these disturbance factors are critical for accurately estimating regional GPP. Deng et al. (2013) and Chapin et al. (2011) stated that disturbance and stand age are closely related to forest structure and functions, which were known to impact terrestrial carbon budgets. Similarly, nitrogen availability was widely recognized as an important control of canopy photosynthesis and even the whole ecosystem carbon dynamics (LeBauer and Treseder, 2008). However, these factors were not accounted for by the WaSSI model due to lack of data over the CONUS. In addition, selection of the land cover product was likely another source of this uncertainty. Different land cover classes correspond to different parameters in the two models, so the landcover classification uncertainty directly introduces errors into flux simulations. Finally, the modeling unit of the WaSSI model is watershed while EC-MOD was run for $1-\mathrm{km}$ grid cell, and thereby there is a large scale mismatch between these two datasets. The WaSSI model used a high resolution land cover product (i.e., $30 \times 30 \mathrm{~m} \mathrm{NLCD}$ ), which may be more accurate for land cover identification when compared to Xiao's $(1 \times 1 \mathrm{~km})$ MODIS land cover map.

Numerous studies have found that the vegetation activity (e.g., plant photosynthesis and LAI) over the regional and global scales 
has increased remarkably (Tucker et al., 2001; Zhou et al., 2001; Piao and Fang, 2003; Wang et al., 2011). Therefore, not considering LAI dynamics over the time might lead some uncertainties into our GPP estimates. In our future work, we would like to parameterize the longer-term LAI (or normalized difference vegetation index; NDVI) series or to couple a dynamic module into the WaSSI model for representing vegetation dynamics. Generally, LUCC could offset or enhance ecosystem productivity depending on the type of land cover transformations (Meyer and Turner, 1994; Foley et al., 2005; Zhang et al., 2014).

In addition to these factors discussed above, climate data as a major driver to the hydrologic processes have a great influence on GPP estimates as well. Climate issues in PRISM for the mountainous regions identified by Oyler et al. (2015) might have resulted in over estimating ET and thus GPP in this study.

\section{Conclusions}

The latest version of the WaSSI model was validated with both decades-long hydrology (i.e., $Q$ and MODIS-ET) and ecosystem productivity data (i.e., EC-MOD GPP) at a broad scale across the 170 NFs. The WaSSI model generally captured the spatial variability of multi-year means for annual $Q$, ET and GPP. The WaSSI model also performed well in matching annual and monthly water yield for most of the 72 USGS gauged watersheds. The WaSSI model generally led to higher GPP estimates than the remote sensing-based method, especially in the winter season. Overall, our assessments showed that the WaSSI model had the capability to reconstruct the long-term forest watershed water and carbon balances at a broad scale. This model evaluation study provides a foundation for future model applications in understanding the impacts of climate variability and change (e.g., extreme droughts) on NFs ecosystem service and function.

\section{Acknowledgements}

This study was funded by the National Science Foundation EaSM program (AGS-1049200) awarded to North Carolina State University, and the Eastern Forest Environment Threat Assessment Center (EFETAC), USDA Forest Service. J. Xiao was supported by NASA's Carbon Cycle Science Program (grant \# NNX14AJ18G) and Terrestrial Ecology Program (grant \# NNX12AK56G).

\section{Appendix A. Supplementary material}

Supplementary data associated with this article can be found, in the online version, at http://dx.doi.org/10.1016/j.foreco.2015.03. 054.

\section{References}

Anderson, R.M., Koren, V., Reed, S., 2006. Using SSURGO data to improve Sacramento Model a priori parameter estimates. J. Hydrol. 320, 103-116. http://dx.doi.org/10.1016/j.jhydrol.2005.07.020.

Averyt, K., Meldrum, J., Caldwell, P.V., Sun, G., McNulty, S.G., Huber-Lee, A., Madden, N., 2013. Sectoral vulnerabilities to changing water resources in the conterminous U.S. Environ. Res. Lett. 8 (035046). http://dx.doi.org/10.1088/ 1748-9326/8/3/035046

Brown, T.C., Hobbins, M.T., Ramirez, J.A., 2008. Spatial distribution of water supply in the coterminous United States. J. Am. Water Resour. Assoc. 6 (44), $1474-$ 1487.

Burnash, RJ.C., 1995, The NWS river forecast system-catchment modeling. In: Singh, V.P. (Ed.), Computer Models of Watershed Hydrology. Water Resources Publications, Littleton, Colorado, pp. 311-366.

Caldwell, P.V., Sun, G., McNulty, S.G., Cohen, E.C., Myers, M.J.A., 2012. Impacts of impervious cover, water withdrawals, and climate change on river flows in the conterminous U.S. Hydrol. Earth Syst. Sci. 16, 2839-2857. http://dx.doi.org/ 10.5194/hess-16-2839-2012.
Chapin, F.S., Matson, P.A., Vitousek, P.M., 2011. Principles of Terrestrial Ecosystem Ecology, second ed. Springer, New York.

Cleugh, H.A., Leuning, R., Mu, Q., Running, S.W., 2007. Regional evaporation estimates from flux tower and MODIS satellite data. Remote Sens. Environ. 106, 285-304.

Daly, C., Neilson, R.P., Phillips, D.L., 1994. A statistical topographic model for mapping climatological precipitation over mountainous terrain. J. Appl. Meteorol. 33, 140-158.

Deng, F., Chen, J.M., Ishizawa, M., Yuen, C.-W., Mo, G., Higuchi, K., Chan, D., Maksyutov, S., 2007. Global monthly $\mathrm{CO}_{2}$ flux inversion with a focus over North America. Tellus B 59, 179-190.

Deng, F., Chen, J.M., Pan, Y., Peters, W., Birdsey, R., McCullough, K., Xiao, J., 2013. The use of forest stand age information in an atmospheric $\mathrm{CO}_{2}$ inversion applied to North America. Biogeosciences 10, 5335-5348.

Fisher, J.B., Tu, K., Baldocchi, D.D., 2008. Global estimates of the land atmosphere water flux based on monthly AVHRR and ISLSCP-II data, validated at FLUXNET sites. Remote Sens. Environ. 112, 901-919.

Foley, J.A., DeFries, R., Asner, G.P., Barford, C., Bonan, G., Carpenter, S.R., Chapin, F.S., Coe, M.T., Daily, G.C., Gibbs, H.K., 2005. Global consequences of land use. Science 309 (5734), 570-574.

Fry, J., Xian, G., Jin, S., Dewitz, J., Homer, C., Yang, L., Barnes, C., Herold, N., Wickham, J., 2011. Completion of the 2006 National Land Cover Database for the conterminous United States. Photogramm. Eng. Remote Sens. 77, 858-864.

Gedney, N., Cox, P.M., Betts, R.A., Boucher, O., Huntingford, C., Stott, P.A., 2006. Detection of a direct carbon dioxide effect in continental river runoff records. Nature 439 (7078), 835-838.

Goodale, C.L., Apps, M.J., Birdsey, R.A., Field, C.B., Heath, L.S., Houghton, R.A., Jenkins, J.C., Kohlmaier, G.H., Kurz, W., Liu, S., Nabuurs, G.-J., Nilsson, S., Shvidenko, A.Z., 2002. Forest carbon sinks in the Northern Hemisphere. Ecol. Appl. 12, 891-899.

Gurney, K.R., Law, R.M., Denning, A.S., Rayner, P.J., Baker, D., Bousquet, P., Bruhwiler, L., Chen, Y.-H., Ciasi, P., Fan, S., Fung, I.Y., Gloor, M., Heimann, M., Higuchi, K., John, J., Maki, T., Maksyutov, S., Masarie, K., Peylin, P., Prather, M., Pak, B.C., Randerson, J., Sarmiento, J., Taguchi, S., Takahashi, T., Yuen, C.-W., 2002. Towards robust regional estimates of $\mathrm{CO}_{2}$ sources and sinks using atmospheric transport models. Nature 415, 626-630.

IPCC, 2014. Climate Change 2013: The Physical Science Basis. Cambridge University Press, $134 \mathrm{p}$.

Jung, M., Reichstein, M., Ciais, P., Seneviratne, S.I., Sheffield, J., Goulden, M.L., Bonan, G., Cescatti, A., Chen, J., de Jeu, R., Dolman, A.J., Eugster, W., Gerten, D., Gianelle, D., Gobron, N., Heinke, J., Kimball, J., Law, B.E., Montagnani, L., Mu, Q., Mueller, B., Oleson, K., Papale, D., Richardson, A.D., Roupsard, O., Running, S., Tomelleri, E., Viovy, N., Weber, U., Williams, C., Wood, E., Zaehle, S., Zhang, K., 2010. Recent deceleration of global land evapotranspiration due to moisture supply limitation Nature 467, 951-954. http://dx.doi.org/10.1038/nature09396.

Koren, V., Smith, M., Duan, Q., 2003. Use of a priori parameter estimates in the derivation of spatially consistent parameter sets of rainfall-runoff models. In: Duan, Q., Sorooshian, S., Gupta, H., Rosseau, H., Turcotte, H. (Eds.), Calibration of Watershed Models Water Science and Applications, vol. 6. AGU, Washington, D.C., pp. 239-254.

Koren, V., Moreda, F., Reed, S., Smith, M., Zhang, Z., 2005. Evaluation of a grid-based distributed hydrological model over a large area, paper presented at the 7th IAHS Scientific Assembly, Foz do Iguaçu, Brazil.

Law, B.E., Falge, E., Gu, L., Baldocchi, D.D., Bakwin, P., Berbigier, P., Davis, K., Dolman, A.J., Falk, M., Fuentes, J.D., Goldstein, A., Granier, A., Grelle, A., Hollinger, D., Janssens, I.A., Jarvis, P., Jensen, N.O., Katul, G., Mahli, Y., Matteucci, G., Meyers, T., Monson, R., Munger, W., Oechel, W., Olson, R., Pilegaard, K., Paw, U.K.T., Thorgeirsson, H., Valentini, R., Verma, S., Vesalaa, T., Wilsons, K., Wofsy, S., 2002. Environmental controls over carbon dioxide and water vapor exchange of terrestrial vegetation. Agric. For. Meteorol. 113, 97-120. http://dx.doi.org/ 10.1016/S0168-1923(02)00104-1.

LeBauer, D.S., Treseder, K.K., 2008. Nitrogen limitation of net primary productivity in terrestrial ecosystems is globally distributed. Ecology 89, 371-379.

Liu, N., Sun, P., Liu, S., Sun, G., 2013. Coupling simulation of water-carbon processes for catchment: calibration and validation of the WaSSI-C model. Chinese J. Plant Ecol. 37 (6), 492-502 (in Chinese with English abstract).

Lockaby, G., Nagy, C., Vose, J.M., Ford, C.R., Sun, G., McNulty, S.G., Caldwell, P.V., Cohen, E., Moore Myers, J.A., 2011. Water and Forests, in Wear, D.N., Greis, J.G., (eds.) The Southern Forest Futures Project: Technical Report, USDA Forest Service, Southern Research Station, Asheville, NC., General Technical Report, 2011.

Marion, D.A., Sun, G., Caldwell, P.V., Miniat, C.F., Ouyang, Y., Amatya, D.M., Clinton, B.D., Conrads, P.A., Gull Laird, S., Dai, Z., Clingenpeel, J.A., Liu, Y., Roehl Jr., E.A., Moore Myers, J.A., Trettin, C., 2014. Managing forest water quantity and quality under climate change. In: Vose, J.M., Klepzig, K.D. (Eds.), Climate Change Adaptation and Mitigation Management Options: A Guide for Natural Resource Managers in Southern Forest Ecosystems. CRC Press, Boca Raton, FL, pp. 249-305.

Masek, J.G., Goward, S.N., Kennedy, R.E., Cohen, W.B., Moisen, G.G., Schleeweis, K., Huang, C.Q., 2013. United States forest disturbance trends observed using Landsat time series. Ecosystems 16, 1087-1104.

McCabe, G.J., Markstrom, S.L., 2007. A monthly water-balance model driven by a graphical user interface, U.S. Geological Survey Open-File report 2007-1088, p. 6.

McCabe, G.J., Wolock, D.M., 1999. Future snowpack conditions in the western United States derived from general circulation model climate simulations. J. Am. Water Resour. Assoc. 35, 1473-1484. http://dx.doi.org/10.1111/j.17521688.1999.tb04231.x.

McKinley, D.C., Ryan, M.G., Birdsey, R.A., Giardina, C.P., Harmon, M.E., Heath, L.S., Houghton, R.A., Jackson, R.B., Morrison, J.F., Murray, B.C., Pataki, D.E., Skog, K.E., 
2011. A synthesis of current knowledge on forests and carbon storage in the United States. Ecol. Appl. 21 (6), 1902-1924.

Meyer, W.B., Turner, B.L., 1994. Changes in Land Use and Land Cover: A Global Perspective. Cambridge Univ. Press, Cambridge.

McNulty, S.G., Cohen, E.C., Sun, G., Caldwell, P., 2015. Chapter 1.7: Hydrologic Modelling for Water Resource Assessment in a Developing Country: The Rwanda Case Study. In: Lafforgue, Michel (Ed.), Watershed Modeling (in press).

Mu, Q., Heinsch, F.A., Zhao, M., Running, S.W., 2007. Development of a global evapotranspiration algorithm based on MODIS and global meteorology data. Remote Sens. Environ. 111, 519-536. http://dx.doi.org/10.1016/ j.rse.2007.04.015.

Mu, Q., Zhao, M., Running, S.W., 2011. Improvements to a MODIS global terrestrial evapotranspiration algorithm. Remote Sens. Environ. 115, 1781-1800.

Myneni, R.B., Hoffman, S., Knyazikhin, Y., Privette, J.L., Glassy, J., Tian, Y., Wang, Y., Song, X., Zhang, Y., Smith, G.R., Lotsch, A., Friedl, M., Morisette, J.T., Votava, P., Nemani, R.R., Running, S.W., 2002. Global products of vegetation leaf area and fraction absorbed PAR from year one of MODIS data. Remote Sens. Environ. 83, 214-231.

Nash, J.E., Sutcliffe, J.V., 1970. River flow forecasting through conceptual models part I-A discussion of principles. J. Hydrol. 10 (3), 282-290.

National Climate Assessment (NCA). 2014. Climate Change Impacts in the United States: The Third National Climate Assessment. U.S. Global Change Research Program http://dx.doi.org/10.7930/J0Z31WJ2.

Natural Resources Conservation Service, 2012. United States Department of Agriculture. U.S. General Soil Map (STATSGO2), Available online at http://soildatamart.nrcs.usda.gov. Accessed 02 February 2012.

Oyler, J.W., Dobrowski, S.Z., Ballantyne, A.P., Klene, A.E., Running, S.W., 2015. Artificial amplification of warming trends across the mountains of the western United States. Geophys. Res. Lett. 42, 153-161.

Pacala, S.W., Hurtt, G.C., Baker, D., Peylin, P., Houghton, R.A., Birdsey, R.A., Heath, L., Sundquist, E.T., Stallard, R.F., Ciais, P., Moorcroft, P., Caspersen, J.P., Shevliakova, E., Moore, B., Kohlmaier, G., Holland, E., Gloor, M., Harmon, M.E., Fan, S.-M., Sarmiento, J.L., Goodale, C.L., Schimel, D., Field, C.B., 2001. Consistent land- and atmosphere-based U.S. carbon sink estimates. Science 292, 2316-2320. http:// dx.doi.org/10.1126/science.1057320.

Piao, S.L., Fang, J.Y., 2003. Seasonal changes in vegetation activity in response to climate changes in China between 1982 and 1999. Acta Geographica Sinica 58 (1), 119-125 (in Chinese with English Abstract).

PRISM Climate Group, 2013. Descriptions of PRISM Spatial Climate Datasets for the Conterminous United States. <http://www.prism.oregonstate.edu/documents/ PRISM_datasets_aug2013.pdf>.

Ryan, M.G., Harmon, M.E., Birdsey, R.A., Giardina, C.P., Heath, L.S., Houghton, R.A., Jackson, R.B., McKinley, D.C., Morrison, J.F., 2010. A synthesis of the science on forests and carbon for U.S. forests. Issues Ecol. 13, 1-16.

National Operational Hydrologic Remote Sensing Center, 2004. Snow Data Assimilation System (SNODAS) Data Products at NSIDC, [accessed 1/20/2015] Boulder, Colorado USA: National Snow and Ice Data Center. <http://dx.doi.org/ 10.7265/N5TB14TC>.

Sun, G., Caldwell, P.V., McNulty, S.G., 2015a. Modeling the potential role of forest thinning in maintaining water supplies under a changing climate across the Conterminous United States. Hydrol. Process. http://dx.doi.org/10.1002/ hyp. 10469.

Sun, S., Sun, G., Caldwell P., McNulty, S.G., Mack, E., Xiao, J., Zhang, Y., 2015b. Drought Impacts on Ecosystem Functions of the U.S. National Forests and Grasslands: Part II Model Application and Results Analysis. Forest Ecol. Manage.

Sun, G., Alstad, K., Chen, J., Chen, S., Ford, C.R., Lin, G., Liu, C., Lu, N., McNulty, S.G., Miao, H., Noormets, A., Vose, J.M., Wilske, B., Zeppel, M., Zhang, Y., Zhang, Z., 2011a. A general predictive model for estimating monthly ecosystem evapotranspiration. Ecohydrology 4, 245-255. http://dx.doi.org/10.1002/ eco.194.

Sun, G., Caldwell, P., Noormets, A., Cohen, E., McNulty, S., Treasure, E., Domec, J.C., Mu, Q., Xiao J, John, R., Chen, J., 2011b. Upscaling key ecosystem functions across the conterminous United States by a water-centric ecosystem model. Journal of Geophysical Research 116 (G00J05) http://dx.doi.org/10.1029/ 2010JG001573.

Sun, G., McNulty, S.G., Moore Myers, J.A., Cohen, E.C., 2008. Impacts of multiple stresses on water demand and supply across the southeastern United States. J. Am. Water Resour. Assoc. 44, 1441-1457. http://dx.doi.org/10.1111/j.17521688.2008.00250.x.
Tavernia, B.G., Nelson, M.D., Caldwell, P.V., Sun, G., 2013. Water stress projections for the northeastern and midwestern United States in 2060: Anthropogenic and ecological consequences. J. Am. Water Resour. Assoc. 49 (4), 938-952. http:// dx.doi.org/10.1111/jawr.12075.

Tian, H., Chen, G., Liu, M., Zhang, C., Sun, G., Lu, C., Xu, X., Ren, W., Pan, S., Chappelka, A., 2010. Model estimates of net primary productivity, evapotranspiration, and water use efficiency in the terrestrial ecosystems of the southern United States during 1895-2007. Forest Ecol. Manage. 259, 1311-1327. http://dx.doi.org/ 10.1016/j.foreco.2009.10.009.

Tucker, C.J., Slayback, D.A., Pinzon, T.E., Los, S.O., Myneni, R.B., Taylor, M.G., 2001 Higher northern latitude NDVI and growing season trends from 1982 to 1999 Int. J. Biometeorol. 45, 184-190.

Vose, J.M., Peterson, D., Patel-Weynand, T. (Eds.), 2012. Effects of Climatic Variability and Change on Forest Ecosystems: A Comprehensive Science Synthesis for the U.S. Forest Sector. General Technical Report PNW-GTR-870. Portland, Oregon: U.S. Forest Service, Pacific Northwest Research Station.

Wang, X.H., Piao, S.L., Ciais, P., Li, J.S., Friedlingstein, P., Koven, C., Chen, A.P., 2011. Spring temperature change and its implication in the change of vegetation growth in North America from 1982 to 2006. Proc. Natl. Acad. Sci. U.S.A. 108 (4), $1240-1245$.

Xiao, J.F., Ollinger, S.V., Frolking, S., Hurtt, G.C., Hollinger, D.Y., Davis, K.J., Pan, Y., Zhang, X., Deng, F., Chen, J., Baldocchi, D.D., Law, B.E., Arain, M.A., Desai, A.R., Richardson, A.D., Sun, G., Amiro, B., Margolis, H., Gu, L., Scott, R.L., Blanken, P.D., Suyker, A.E., 2014. Data-driven diagnostics of terrestrial carbon dynamics over North America. Agr. Forest Meteorol. 197, 142-157.

Xiao, J., Zhuang, Q., Baldocchi, D.D., Law, B.E., Richardson, A.D., Chen, J., Oren, R., Starr, G., Noormets, A., Ma, S., Verma, S.B., Wharton, S., Wofsy, S.C., Bolstad, P.V. Burns, S.P., Cook, D.R., Curtis, P.S., Drake, B.G., Falk, M., Fischer, M.L., Foster, D.R., Gu, L., Hadley, J.L., Hollinger, D.Y., Katul, G.G., Litvak, M., Martin, T.A., Matamala, R., McNulty, S., Meyers, T.P., Monson, R.K., Munger, J.W., Oechel, W.C., Paw, U.K.T., Schmid, H.P., Scott, R.L., Su, G., Suyker, A.E., Torn, M.S., 2008. Estimation of net ecosystem carbon exchange for the conterminous United States by combining MODIS and AmeriFlux data. Agric. For. Meteorol. 148, 1827-1847.

Xiao, J., Zhuang, Q., Law, B.E., Baldocchi, D.D., Chen, J., Richardson, A.D., Melillog, J.M., Davish, K.J., Hollingeri, D.Y., Wharton, S., Orenk, R., Noormets, R., Fischerm, M.L., Verman, S.B., Cooko, D.R., Sun, G., McNulty, S., Wofsy, S.C., Bolstad, P.V., Burns, S.P., Curtis, P.S., Drake, B.G., Falk, M., Fosterv, D.R., Gu, L., Hadley, J.L., Katul, G.G., Litvaky, M., Ma, S., Martin, T.A., Matamala, R., Meyers, T.P., Monsons R.K., 2011. Assessing net ecosystem carbon exchange of U.S. terrestrial ecosystems by integrating eddy covariance flux measurements and satellite observations. Agric. For. Meteorol. 151, 60-69.

Xiao, J., Zhuang, Q., Law, B.E., Chen, J., Baldocchi, D.D., Cook, D.R., Oren, R., Richardson, A.D., Wharton, S., Ma, S., Martin, T.A., Verma, S.B., Suyker, A.E., Scott, R.L., Monson, R.K., Litvak, M., Hollinger, D.Y., Sun, G., Davis, K.G., Bolstad, P.V., Burns, S.P., Curtis, P.S., Draket, B.G., Falk, M., Fischer, M.L., Foster, D.R., Gu, L., Hadley, J.L., Katulg, G.G., Matamala, R., McNulty, S., Meyers, T.P., 2010. A continuous measure of gross primary production for the conterminous United States derived from MODIS and AmeriFlux data. Remote Sens. Environ. 114, 576-591.

Xiao, J.F., Zhuang, Q., Liang, E., McGuire, A.D., Moody, A., Kicklighter, D.W., Melillo J.M., 2009. Twentieth century droughts and their impacts on terrestrial carbon cycling in China. Earth Interactions 13 (10), 1-31. http://dx.doi.org/10.1175/ 2009EI275.1.

Xie, J., Chen, J.G., Sun, G., Chu, H., Noormets, A., Ouyang, Z., John, R., Wan, S., Guan, W., 2013. Long-term variability and environmental control of the carbon cycle in an oak-dominated temperate forest. For. Ecol. Manage. 313, 319-328.

Zhang, L., Wylie, B.K., Ji, L., Gilmanov, T.G., Tieszen, L.L., Howard, D.M., 2011. Upscaling carbon fluxes over the Great Plains grasslands: Sinks and sources. J. Geophys. Res., 116 (G00J03), doi:101029/2010JG001504.

Zhang, Y., Song, C., Zhang, K., Cheng, X., Band, L.E., Zhang, Q., 2014. Effects of land use/land cover and climate changes on terrestrial net primary productivity in the Yangtze River Basin, China, from 2001 to 2010. J. Geophys. Res. Biogeosci. 119, 1092-1109. http://dx.doi.org/10.1002/2014JG002616.

Zhao, M., Running, S.W., 2010. Drought-induced reduction in global terrestrial net primary production from 2000 through 2009. Science 329, 940-943.

Zhou, L.M., Tucker, C.J., Kaufmann, R.K., Slayback, D., Shabanov, N.V., Myneni, R.B. 2001. Variations in northern vegetation activity inferred from satellite data of vegetation index during 1981 to 1999. J. Geophys. Res. 106 (17), 20069-20083. 